\title{
A STUDY OF INMATE ARGOT IN ROMANIAN PRISONS
}

\author{
Prof. Lavinia NĂDRAG, Ph.D \\ Ovidius University, Constanța \\ lnadrag28@yahoo.com \\ Manuela STROESCU, Ph.D
}

\begin{abstract}
The lexis and structure of prison argot reflect the personalities of inmates who employ them, as well as the conflicts and tensions inherent in prison settings. It is shown in this article that the distinctiveness of prison argot is largely a product of the character of penal context. Its extent of use varies with the extent of penal discipline. Appreciation of this complex relationship might facilitate improved communication between prisoners and custodial authorities. In addition, knowledge of prison argot meanings has a potential to improve the management of prison-based programs and thus appears helpful in the complex process of prisoners' rehabilitation and social reintegration.
\end{abstract}

\section{UN STUDIU ASUPRA ARGOULUI DIN PENITENCIARELE ROMÂNEŞTI}

Rezumat: Lexicul şi structura argoului din închisori reflectă atât personalitatea condamnaţilor care le utilizează, cât şi conflictele şi tensiunile inerente în închisori. În acest articol, se arată că particularitățile argoului din închisori sunt, în mare măsură, un produs al caracterului contextului penal. Utilizarea sa variază în funcție de disciplina penală. Cunoaşterea acestei relaţii complexe ar putea facilita comunicarea dintre persoanele private de libertate şi autoritățile care le au în custodie. În plus, cunoaşterea sensurilor argoului penitenciar are potențialul de a îmbunătăti managementul programelor din penitenciar şi, astfel, poate fi de mare ajutor în procesul complex de reabilitare şi reintegrare socială a condamnaților.

Key words: study, argot, slang, inmate, prison

1. An obvious reason for choosing to concentrate on slang is because slang itself has become a controversial and spectacular social and linguistic phenomenon - it has gone global and it is one of the most important linguistic tools and verbal communication methods of people.

Slang pervades speech alarmingly and its popularity can be measured by the rush of journalists, politicians and promulgators of popular culture to take up the latest word or phrase to spice up a newspaper headline, defy speech, an advertisement or a television script. On the other hand, prescriptive guardians of standard language and morality complain of slang's "degrading" effect on public discourse and culture. Slang is unconventional, hard-hitting, metaphorical, colloquial, sometimes vulgar and always innovative. With slang, each generation or subculture group has the chance to shape and propagate its own lexicon, and in so doing, to exercise originality and imagination.

The recorded slangs of the past have been characterised by Halliday (1978) in terms of 'antilanguages', the secretive codes of transgressive or deviant subcultures - 


\section{Comparative Legilinguistics 4/2010}

criminals, beggars, travelling entertainers - with their salient features of relexicalisation and overlexicalisation.

The world has been radically transformed by immigration, industrialization, urbanization and mass communication. Because of these changes slang has permeated everyday speech.

Sociolinguists have focused on the role of adolescent slangs in the construction of social identity, among, for example, street gangs or high school students (Labov 1982, Eckert 1989), showing how acceptance into and exclusion from peer-groups is mediated by slang nomenclature and terminology. Researchers into slang usage have tended to concentrate on the links between language and hierarchies, status and deployment of social capital.

Eble (1996) has shown that the slang of middle-class college students is more complex and less a product of alienation than has been assumed in the past. Her recordings of interactions reveal that the selective and conscious use of slang itself is only part of a broader repertoire of style-shifting in conversation, not primarily to enforce opposition to authority, secretiveness or social discrimination, but often for the purposes of bonding and 'sociability' through playfulness.

There are now local hybrids - not only in the English lexis - often incorporating alongside the pervasive effects of dominant inner-circle varieties such as the high school argot propagated by Hollywood movies and TV soaps, and the black street codes of rap and hip-hop. The concept of authenticity is complicated by the development in the media and in literature of pseudo-slangs. So called virtual or electronic literacies developing for the Internet, email or text messaging have generated new slangs and an enormous proliferation of websites designed to decode them.

2. Slang's primary reason for being is to establish a sense of commonality among its speakers. When slang is used, there is a subtext to the primary message which speaks about the speaker's and listeners' membership in the same "tribe". Slang plays a critical role whether it delineates winner (e.g. the Romanian forms bastan, barosan; Diesel, cool, trendy) from loser (defect, distrus, terminat), or oppressor (bazat, ciumec, faraon, mascul alfa, patron, şmecher) from oppressed ( retard).

Slang is much more effective than standard language when it comes to describing sports, sex, intoxication, economy, religion or even foreign policy. Informal and spoken rather than formal and written, slang is not the same as dialect, nor is it equal to swearing, although it may take on a vulgar edge, and it almost always evokes negative attitudes.

Slang is also known for its fertility; it reproduces itself in abundance with each new generation. At any given moment, there are many slang words and expressions in use across the country. By a semantic process akin to natural selection, only the strong terms or phrases survive, spreading from the regional, cultural, age or ethnic group in which they are coined. The rest are quickly discarded and forgotten (Astaloş 2002).

Some of the factors that are the most likely to produce slang are youth, oppression, sports and vice. They provide an impetus to coin and use slang for different sociolinguistic reasons. Most slang coinages are local in both time and place; much of it, like other cultural phenomena, originates in large cities. What differentiates slang from other categories of speech (such as jargon or argot) is one's reasons for using it. 
Eric Partridge (1953) identifies several reasons for using slang, including the desire to be different, novel, or picturesque; to enrich the language; to engage in playfulness; to identify oneself with a certain school, trade, or social class; to reduce or disperse the pomposity or excessive seriousness of an occasion; to be secret. Slang is always used self-consciously, with a desire to create a particular identity.

3. The previous reluctance of Romanian scholars in the 1970's to admit slang terms has given way to a slight tendency of embracing this informal level of lexis. English etymology would place vocabulary labelled fam., pop. and vulg. in Romanian under the general heading slang. The term argot has distinguishably passed into English by being more secret, less public, less generally available and "less respectable" (Edwards 1976: 23). Slang and argot possess low social value, but it seems that slang has a highly significant role to play in the linguistic life of the community. Some researchers consider that the rigid codification of the standard language triggers a proliferation of non-standard forms. These "deviant" forms cannot be ignored by linguists.

Slang has been approached differently. Romanian researchers A. StoichiţoiuIchim (2001) and R. Zafiu (2001), for example, demonstrate the interest contained in the morphology of contemporary Romanian slang. Traditional interest in slang is heavily prescriptive, being preoccupied with grading colloquial words according to their fitness for use in polite society. Argot has received close attention, being a field of enquiry rich in the exotic and the bizarre, and it has been studied with enthusiastic intensity elsewhere.

For sociolinguists, the colloquial, vernacular usage, far from being something to be eliminated, is the main focus of interest. Variation in language, instead of being an accidental, dysfunctional element which impedes efficient communication, and which should be suppressed, is crucial to the effective functioning of a language. Three features of language variation are taken as axiomatic by sociolinguists \{ see Labov 1982):

(i) Variability is inherent in language and central to its social role. Without it we would be incapable of communicating all types of nuances in our everyday use of language, in particular, vital information about our personal identity;

(ii) There are no natural breaks between language varieties, no pure homogeneous styles and dialects, no neat word boxes, only gradations along social and stylistic continua;

(iii) Language variation is emphatically not "free". It is not randomly occurring or

linguistically redundant. It correlates in a complex but nevertheless structured way with factors outside language, speaker variables like age, sex, social class, etc., and situational variables like the degree of formality, the relationship with the addressee, etc. Slang is also a self-therapy, the defence of the ego against the oppressing community.

Little is known, however, about how slang is used as part of everyday spoken and written discourse. Survey-based studies tend to present their findings in the form of a mini-lexicon or glossary, in which terms are listed alphabetically and definitions are supplied by the researcher on the basis of survey responses. A more discourse-centered approach can redress some of the omissions of earlier scholarship.

In discourse, slang is a resource that speakers use to lay claim to a variety of identities based on age, region, race and ethnicity, and subcultural participation, as well 


\section{Comparative Legilinguistics 4/2010}

as to achieve particular local goals in interaction. And it is within discourse that the meaning of slang terms emerges - both at the semantic level of sense and reference and at the semiotic level of speakers' identities, ideologies, and practices.

4. In considering slang as a discursive phenomenon, this paper expands on traditional approaches to the lexicon within sociolinguistics, in which lexical items from a particular semantic field (e.g. kinship, metalinguistics) or linguistic variety (e.g., slang, regional Romanian) are extracted from discourse and organized in the form of an inventory or taxonomy. As scholars are well aware, however, linguistic phenomena are not decontextualized structures but contextually embedded social practices (an insight to which our lexical research contributed).

4.1. The present study (see Stroescu 2008) builds on the insights of previous researchers to argue that by its very nature, slang is a rich resource both for the negotiation of meaning and for the production of social and interactional identities linked to these meanings. Slang is particularly well suited to the construction of identity for several reasons. First, as part of the lexicon, it operates above the level of conscious awareness and thus is easily used and recognized. Second, as one of the most socially meaningful kinds of lexis, it can provide nuanced and detailed information about the speaker's identity. And third, because it is prone to rapid change, its progress across the social terrain can be tracked with relative ease.

The elicitation of slang is an invaluable source of ideologies relating to social identities, particularly language ideologies. In addition, we found evidence for slang use in practice in prisoners'vernacular writing such as diaries, letters, graffiti, and personal notes, as well as in the observation and recording of interaction. The combination of ideology-based and practice-based perspectives revealed the multifunctionality of slang in the discursive construction of various kinds of identity among inmates at a Romanian penitentiary. The main characteristics of the prison environment and confinement life are mirrored in prisoners' communication and argot. Our study shows that an inmate argot exists in Romanian prisons and its components significantly derive of prisoners' inner world. Prisoners develop their own system of norms, values, and behaviors which serves as the core of inmate subculture. Communication in prisons is accomplished both through common language and through argot, the prisoners' own language (inmate jargon) that conveys its specific messages and defines its rules and behaviors. Moreover, mastery of argot reflects the personal background of a criminal and their status in prison.

\section{METHOD}

The design of the study was intentionally flexible to accommodate the data as they emerged and, thereby, enhance both the quality and the authenticity of the findings (see Briggs, 1986). This approach allowed access to contents that were not anticipated a priori and exploration of the research topic from the standpoint of the research population, namely, the inmates (see Silvermann 1993).

The contextual-dynamic method was used to collect information from the inmate participants. This method is mainly concerned with observation and dialogues (see Slama- Cazacu, 1959, 1999, 2000). The interview was based on general guidelines to ensure that all those being interviewed would be subject to similar stimuli and, thereby, allow for a common base for data analysis.

\section{POPULATION}


The participants in the study consisted of 20 randomly selected Romanianspeaking male prisoners serving different term sentences (between 1 and 10 years) in the Romanian prison system.

\section{PROCEDURE}

The interviews were held in different locations and at different time sessions, each lasting from lo minutes to approximately 1 hour. Interviewees were encouraged to share their experiences with the interviewer in a setting conducive to a sense of interpersonal involvement. The concerned parts of the interviews were written down with the consent of the interviewees.

\section{DATA ANALYSIS}

In view of their essentially qualitative nature, the data were subjected to content analysis (see Strauss \& Corbin 1990; Weber 1990). The argot terms were divided into six main categories: (a) prisoner status (informers, inmate rank), (b) drugs, (c) sexual relations in the prison, (d) violence, (e) nicknames for police officers and prison staff, and (f) other.

We assessed the importance assigned to a given category or topic as reflected by its connotation (e.g., positive, negative) and the number of terms assigned to it (see Krippendorff 1980). The analysis is, therefore, essentially thematic and based on categorization of content areas. This system serves to pinpoint the most salient norms and values of the inmate code and the thinking patterns that typify the research population.

\subsection{RESULTS AND DISCUSSION}

The findings showed that an inmate argot clearly exists in Romanian prisons. Over 500 argot terms were identified. The unique nature of the argot terms and expressions is clearly demonstrated by the fact that virtually none of them are to be found in the pages of a regular Romanian dictionary, nor in the very few ("general") slang dictionaries existent in Romania.

\section{- PRISONER STATUS: INFORMERS, INMATE RANK}

A significant number of argot expressions reflected the importance of loyalty and adherence to the inmate behavioral code such as "never to inform on a fellow inmate". Argot expressions related to this aspect of the prison subculture were associated with high intensity: at least ten different terms were used to describe informers. This high intensity reflects the strong negative sanctions applied for infraction of this code (verbal and physical violence, social isolation, withholding food, withdrawal of commodities such as cigarettes and drugs).

On the other side of the same coin, eight expressions were identified describing prisoners who adhere to the code and never betray their prison mates. Such inmates (called "right guys" or "good guys" in the US) are characterized not only by loyalty to the code of conduct but also by their ability to stay "cool", maintain their selfrespect, never show weakness, and help other prisoners, irrespective of the severity of sanctions imposed on them by the custodial staff.

This point is very important in view of personal benefits - psychological and social - stemming from opposition to prison policies. Such prisoners gain satisfaction from active or passive acts against the prison authorities. The aim of such acts is not to "win" but to demonstrate a degree of personal autonomy. In return, they are held in high 


\section{Comparative Legilinguistics 4/2010}

esteem by their fellowinmates and, over the course of time, may become leaders or arbitrators.

\section{- DRUGS}

Prison inmates naturally seek out ways to compensate themselves for the "pains of imprisonment" (see Bondesson 1989); hence, the active, albeit covert, commodity market within the prison. Participation in the market also serves an important psychological function for inmates -creating a sense of control over their destiny and satisfaction at outwitting the prison supervision system.

Drugs are the most highly valued commodity in the inmate economic system. Indeed, drugs are so central and dominant in prison life that it can be fairly stated that they form the backbone of inmate culture. Their high demand stems from the large financial profit to be gained from drug sales, the fact that many inmates are regular drug users, and the tendency of many nonusers to seek temporary "escape" from the stresses and tensions of prison life by means of drugs (see Parisi 1982). The importance of drugs and drug dealers in the prison is expressed by a wide variety of argot terms. These terms can be grouped into several subcategories: names of drugs, quantity of drugs, ways of use or administration, smuggling methods, drug effects, and the state of the drug market.

The critical importance of drugs in the prison sometimes serves to override the primacy of inmate loyalty. A number of inmates reported that they would be ready to betray their friends and the inmate code of conduct for the sake of the drug. Some stated that they would even be ready to harm a drug user who returned from leave without bringing back a drug supply.

\section{- SEXUAL RELATIONS}

Deprivation from heterosexual relationships constitutes one of the most significant pains of imprisonment (see Bowker 1980; Hawkins \& Alpert, 1989).

Data indicate that the incidence of homosexual intercourse has decreased and the argot once used neutrally to describe it is now used derogatively to express negative sanctioning of such behavior. Although many of the argot expressions in this area have not changed, their contextual meaning has, for example, hamburger is used to describe homosexual intercourse, pipa is used to describe oral sex. In the line with delegitimation of sex among the inmates, many sexual terms are now used to express contempt of prisoners, regardless of their sexual preference or conduct.

\section{- VIOLENCE}

Power struggles between different groups of prisoners, often expressed by violence, are a common feature of prison life. This phenomenon creates a climate of fear in the prison and serves to accentuate gaps between weaker and stronger inmates. There is a strong connection between environmental conditions and conduct (e.g., mental illness, violence, habitual offences).

There are some other characteristics of the prison environment and inmate life which clearly pertain in Romanian prisons: overcrowding, boredom, economics.

\section{- NICKNAMES FOR POLICE OFFICERS AND PRISON STAFF}

According to Irwin (1985), when people are forced to cope with stress, they seek out optimal ways to avoid pain and gain social support. The prison regime sets exceptionally severe obstacles to inmate adjustment. Irwin (1985) and Johnson (1987) argue that prison policies and their implementation (formal and informal) contain a clear element of intentional malice and cruelty. This is because members of the penal system, 
like most of the public, believe that inmates are bad people who deserve to be rejected and treated mercilessly. As a totalitarian institution, one of the main aims of the prison is to ensure inmate subordination by imposing strict rules and restrictions with harsh penalties for noncompliance.

The humiliation experienced by the inmate peaks when he finds himself housed in an overcrowded cell (Irwin, 1985) and when he discovers that his custodians know him by the details connected to his crime but have no interest in his individual needs, anxieties, or other personal problems. As a rule, inmates relate to the prison authorities in a negative manner, expressing contempt and tremendous anger toward them. The argot nicknames assigned to prison staff are as humiliating as possible, and encounters with staff are described in terms of power and inequality (David and Goliath), the weak prisoner always suffering and the bad, powerful prison guard always abusive. These descriptions are seasoned with aggressive expressions and a strong drive for revenge.

However, it should be noted that inmate attitudes toward the custodial staff are characterized by ambivalence: on the one hand, hatred, distrust, and negativism (Bondesson 1989) and on the other, due to their power and capacity to influence the lives of inmates, deference and subordination (Johnson 1987).

- ARGOT STYLE

According to Irwin (1980), the harsh realities of prison life induce linguistic inventiveness and improvisation. Clemmer (1940) noted that of all the different factors that influence the development of a unique vocabulary in prison, humor, imagination, and cynicism are the most salient. Indeed, the linguistic recreation and humor that characterize the inmate argot is perceived as a way of coping with the harsh conditions of the prison environment (overcrowding, excessive noise, lack of basic comforts) and achieving in-group exclusivity (secrecy) and social cohesiveness (Partridge, 1970). Imagination and creativity are highly evident in the argot of Romanian prisoners, and many of the argot expressions feature a degree of cynicism.

\section{CONCLUSIONS}

The findings of the present study show that an inmate argot clearly exists in Romanian prisons. The findings also support the notion that inmates do not feel any obligation to adhere to codes and norms. Accordingly, prisoners develop their own system of norms, values, and behaviors which serves as the core of inmate subculture.

Like any language, argot is dynamic and likely to change: new words and expressions are invented, and old words acquire different meanings in new contexts - in this case, the prison context (Elaine, 1982). The findings of this explorative study clearly demonstrate the contextual roots and the underlying mechanisms of Romanian inmate argot. Innovation and changes in the content of the argot are dynamic, imaginative, and creative and spread quickly throughout the inmate community. Metaphors and creative elements are adopted for their entertainment and illustrative value, for their power to attract the attention of listeners, as well as to soften the harsh realities of prison life and to ensure secrecy and group cohesiveness (Partridge, 1970). These elements are clearly apparent in Romanian inmate argot. 


\section{Comparative Legilinguistics 4/2010}

The present study, the first of its kind to be conducted in Romania, succeeded in identifying several aspects of the prison subculture and the code of Romanian inmates through their use of argot. Qualitative analysis of the attention and intensity of the argot expressions revealed the importance and significance attributed to components of the code by the prisoners. The highest level of intensity was found for "adherence to the inmate code and loyalty to fellow prisoners." Attention was highest for "drugs," as indicated by the many argot terms related to this category. Note, however, that this may stem from the need for a large vocabulary to accommodate the wide variety of drugs and the need for terms to describe their transfer, sale, and so forth. Violent behavior and domination are also expressed through argot, and the terms and expressions themselves may have a significant effect on a prisoner's status. Indeed, in many cases, not only do these terms describe the situation of an individual but they also serve to create it.

In sum, the present research into the argot used by prisoners succeeded in uncovering a number of important aspects of the norms and values of the inmate subculture of Romanian prisons as well as significant components of their inner world. It is suggested that in-depth understanding of this type may, in turn, serve as a supporting tool in assessing the pain, distress, and needs of prisoners in an attempt to help them overcome such difficulties and seek out efficient coping strategies.

\section{Bibliography}

Astaloş, George. 2002. Pe muchie de şuriu: cânturi de ocnă cu microglosare argotice. Bucureşti: Tritonic.

Bondesson, Ulla. 1989. Prisoners in prison societies. New-Brunswick. NJ: Transaction.

Bowker, L. H. 1980. Prison victimization. New York: Elsevier.

Briggs, Charles. 1986. Learning how to ask: A sociolinguistic appraisal of the role of the interview in social science research. Cambridge: Cambridge University Press.

Clemmer, Donald. 1940. The prison community. New York: Rinehart.

Eble, Connie. 1996. Slang and Sociability. London and Chapel Hill: University of North Carolina Press.

Eckert, Penelope. 1989. Jocks and Burnouts: Social Categories and Identity in High School. New York: Teacher's College Press.

Elaine, Chaika. 1982. Language: The social mirror, Rowley, MA: Newbury House.

Halliday, M.A.K. 1978. Language as Social Semiotic: The Social Interpretation of Language and Meaning. London: Edward Arnold.

Hawkins, Richard., and Alpert Geoffrey. 1989. American prison systems, Englewood Cliffs, NJ: Prentice-Hall.

Irwin, John. 1980. Prisons in turmoil. Boston: Little, Brown.

Irwin, John. 1985. The jail. Berkeley: University of California Press.

Johnson, E.H. 1987. Handbook on crime and delinquency prevention. New York: Greenwood Press.

Krippendorff, Klaus. 1980. Content analysis, An introduction to its methodology. Beverly Hills, CA: Sage. 
Labov, Teresa. 1982. Social structure and peer terminology in a black adolescent gang. Language and Society 2: 391-411.

Parisi, Nicolette. 1982. Coping with imprisonment. Beverly Hills, CA: Sage. Partridge, Eric. 1953. A Dictionary of American Slang and Unconventional English. New York: Macmillan.

Paul.

Partridge, Eric. 1970. Slang today and yesterday. London: Routledge, Kegan \&

Silvermann, David. 1993. Interpreting qualitative data: Methods for analyzing talk, text and introduction. London: Sage.

Slama-Cazacu, Tatiana. 1959. Limbaj şi context. Bucureşti: Ed. Ştiințifică.

Slama-Cazacu, Tatiana. 1999. Psiholingvistica, o ştiință a comunicării. Bucureşti: Ed. ALL.

Slama-Cazacu, Tatiana. 2000. Stratageme comunicaționale şi manipularea. Iaşi: Polirom.

Stoichițoiu-Ichim, Adriana. 2001. Vocabularul limbii române actuale. Dinamică, influențe, creativitate. Bucureşti: Ed. ALL.

Strauss, Anselm, and Juliet Corbin. 1990. Basics of qualitative research: Grounded theory procedures and techniques. Newbury Park, CA: Sage.

Stroescu, Manuela. Argoul în comunicarea interlopă dobrogeană, [On-line]. Available: http://www.univ-ovidius.ro/stiri-si-noutati/downloads/rezumat-stroescu.pdf

Weber, R. P. 1990. Basic content analysis, Newbury Park, CA: Sage.

Zafiu, Rodica. 2001. Diversitate stilistică în româna actuală. București: Ed. Universităţii din Bucureşti. 
Comparative Legilinguistics 4/2010 